\title{
A methodological approach to the reconstruction of the 1949-2000 water temperature series in the Ebro River at Escatrón
}

\author{
Jordi Prats ${ }^{1,4, *}$, Rafael Val ${ }^{2,4}$, Joan Armengol ${ }^{3,4}$ and Josep Dolz ${ }^{1,4}$
}

${ }^{1}$ Departamento de Ingeniería Hidráulica, Marítima y Ambiental, ETSECCPB, Universidad Politécnica de Cataluña, Campus Nord UPC, C/ Jordi Girona 1-3, Edif. D1. 08034 Barcelona, España.

2 Facultad de Ingeniería, UNAM, Ciudad Universitaria, Av. Universidad 3000, 04510 México D.F., México.

3 Departamento de Ecología, Facultad de Biología, Universidad de Barcelona, Av. Diagonal 645, 08028 Barcelona, España.

4 FLUMEN-Fluvial Dynamics Research Group.

*Corresponding author: jordi.prats-rodriguez@upc.edu

\begin{abstract}
A methodological approach to the reconstruction of the 1949-2000 water temperature series in the Ebro River at Escatrón

Water temperature is one of the main variables influencing freshwater organisms. In recent years, increasing water temperature trends have been observed in freshwater ecosystems worldwide. To assess the importance of such increases, they need to be put into context by studying long-term water temperature variability. However, it is often difficult to obtain a sufficiently long data series. This problem may be overcome by using data collected by different entities in different periods of time. However, this can lead to data comparability problems. In this paper, we present the process of reconstructing the annual mean water temperature series for the Ebro River at Escatrón using data measured by the Escatrón power station, the Ebro Hydrographic Confederation and the Flumen research group. The data sources used different measurement methodologies and frequencies. Therefore, particular attention was paid to analysing the bias of the annual mean water temperature estimations calculated from the available historical data. A resampling methodology applied to 10-minute water temperature data was performed to assess the quality of the different estimators used to calculate the annual mean water temperature. Only one of the three estimators used could be considered to be unbiased. Another estimator could be corrected by estimating its bias. As a result, it was possible to reconstruct a water temperature series from 1949 to 2000, with a gap in the period 1978-1995. The series shows that there was an increase of $2.3^{\circ} \mathrm{C}$ in the period $1955-2000$.
\end{abstract}

Key words: Bias, Ebro River, historical data, long-term trend, resampling, unbiased estimator, water temperature, water temperature increase.

\section{RESUMEN}

Una aproximación metodológica a la reconstrucción de la serie de temperatura del agua del 1949 al 2000 en el río Ebro en Escatrón

La temperatura del agua es una de las principales variables que influyen sobre los organismos de agua dulce. En los últimos años, se han observado tendencias al aumento de la temperatura en ecosistemas de agua dulce en diferentes partes del mundo. Para determinar la importancia de este aumento es necesario ponerlo en contexto estudiando la variabilidad a largo plazo de la temperatura del agua. No obstante, a menudo es difícil obtener series de datos suficientemente largas. Este problema puede ser solucionado recurriendo a series de datos recogidos por diferentes entidades en diferentes periodos de tiempo. Aparece entonces el problema de la comparabilidad de los datos. En este artículo, se presenta el proceso de reconstrucción de la serie de la temperatura media anual del agua en el río Ebro en Escatrón usando datos medidos por la central térmica de Escatrón, la Confederación Hidrográfica del Ebro y por el grupo de investigación Flumen. A causa de los diferentes métodos de medida y frecuencia de los muestreos de cada una de las series de datos usadas, se dio especial atención al análisis del sesgo de las estimaciones de la temperatura media anual calculadas a partir de los datos históricos disponibles. Una metodología de remuestreo aplicada a datos de temperatura del agua 10-minutales fue usada para establecer la calidad de los diferentes estimadores usados para obtener la temperatura media anual del agua. De los tres estimadores usados sólo uno pudo ser considerado insesgado. De los otros dos, otro pudo ser corregido mediante la estimación del valor de su sesgo. 
Como resultado, fue posible reconstruir una serie de temperaturas desde 1949 hasta 2000, con un vacío de datos en el periodo 1978-1995. La serie muestra un incremento de la temperatura media anual del agua de $2.3^{\circ} \mathrm{C}$ en el periodo 1955-2000.

Palabras clave: Aumento de la temperatura del agua, datos históricos, estimador insesgado, remuestreo, río Ebro, sesgo, tendencia a largo plazo, temperatura del agua.

\section{INTRODUCTION}

Long-term water temperature increases related to climate warming and human alterations have been observed in freshwater ecosystems (Webb \& Nobilis, 1994; Livingstone, 2003). Freshwater organisms are mostly ectotherms and are therefore greatly influenced by water temperature. Some reviews of the general ecological consequences of a temperature increase can be found in McCarty (2001) and Walther et al. (2002). Other authors specifically review the expected effects of climate warming on freshwater ecosystems (Schindler, 1997; Álvarez Cobelas et al., 2005).

According to McCarty (2001) and Walther et al. (2002), biological changes due to warming can occur on four organization levels: (1) physiology and phenology, (2) distribution areas, (3) the composition of communities and interactions between their elements, and (4) ecosystem functioning. At the physiological level, some of the expected consequences of an increase in water temperature are life-cycle changes (Hellawell, 1986; Winfield \& Nelson, 1991), accelerated growth (Negus, 1966; Wieser et al., 1988; Hogg \& Williams, 1996), and shorter development times (Rempel \& Carter, 1987; Pritchard et al., 1996). Shifts in the distribution of species are expected, which will favour the arrival of allochthonous species (Schindler, 1997; Walther et al., 2002) and the expansion of epidemic diseases (Harvell et al., 2002). At the community level, changes in composition can be expected (McCarty, 2001; Walther et al., 2002). Other effects, such as altered sex ratios, may also appear (Hogg \& Williams, 1996). In addition, variations in water temperature may alter the competitive interactions between freshwater species (Beauchamp \& Ullyott, 1932; Reeves et al., 1987; Taniguchi et al., 1998). In lenitic ecosystems, climate warming can cause an increase in thermal stability and a lengthening of the stratification period (Schindler, 1997; Livingstone, 2003).

In the case of Spain, a better knowledge of the scales of variability and the trends of natural processes (e.g. water temperature behaviour) is needed in order to assess the impact of changes in their natural behaviour (Álvarez Cobelas et al., 2005). Air temperature has been measured for more than a century at numerous locations, but water temperature has not received so much attention. This makes it difficult to fill the gap in knowledge about freshwater temperatures. Except in some cases (e.g. Webb \& Nobilis, 1994, 1997), long water temperature series are not available. The Ebro Hydrographic Confederation (CHE) started measuring water temperature in the 1970s. Water quality measurements were also made by industries or power plants at earlier dates. However, their data have rarely been saved for several reasons. Data legal conservation requirements may have expired; the data could have been recorded in electronic devices that are now out of date; or the paper files may have been lost or deteriorated. Although it is sometimes possible to obtain data from different sources so that a series or parts of it can be reconstructed, the measuring methodologies used by these sources may be different. This means that the comparability of the data must be assessed. In addition, the measurement methodology used may lead to a bias in the estimation of the annual mean water temperatures (Arrúe \& Alberto, 1986; McAdam, 2000; Preece \& Jones, 2002).

In order to improve knowledge about the long-term water temperature behaviour in the middle Ebro River, the water temperature series at Escatrón was reconstructed. Data from different sources (the Escatrón thermal power station, 
the Ebro Hydrographic Confederation and our research group), obtained using different methodologies (i.e. measurements of the daily maximum and minimum water temperature, the water temperature being taken at a given time of the day, the water temperature being taken at a variable time) and periodicities (i.e. monthly, daily, every 10 minutes) were used to reconstruct a 52-year long annual mean water temperature series. The accuracy of the annual mean water temperature estimations obtained from the historical data was assessed by means of a resampling methodology and by 10-minute water temperature measurements taken by the Flumen research group in the middle and lower Ebro River. This paper updates the studies undertaken by Arrúe \& Alberto (1986) and Alberto \& Arrúe (1986) on the middle Ebro River.

\section{STUDY AREA}

The Ebro River basin has an area of about $85000 \mathrm{~km}^{2}$ and covers a major part of the northeast of the Iberian Peninsula. The Ebro River had an annual discharge of $17000 \mathrm{hm}^{3}$ in a natural regime in the period 1940/41-1995/96 (MIMAM, 2000). The monthly distribution of the discharge depends mainly on rain and snow-melt. Its major tributaries are the rivers Segre, Cinca, Aragón, Arga and Gállego. In the Ebro River basin there are more than 107 reservoirs of more than $1 \mathrm{hm}^{3}$ and about 800000 ha of irrigated land.

The historical water temperature series was reconstructed at Escatrón (Fig. 1), which is located in the Ebro River depression in the middle course of the river, some kilometres upstream from the Mequinenza reservoir tailwaters. The mean annual discharge in the period 1945/46-1995/96 in Sástago, which is located $17 \mathrm{~km}$ upstream from Escatrón, was $250 \mathrm{~m}^{3} / \mathrm{s}$ (www.chebro.es). A coal-fired power station is located on the outskirts of Escatrón. It uses water from the Ebro River for cooling and has been measuring water temperature since the 1950s upstream from the cooling water efluent. Part of the data used in this study was kindly provided by this power station.

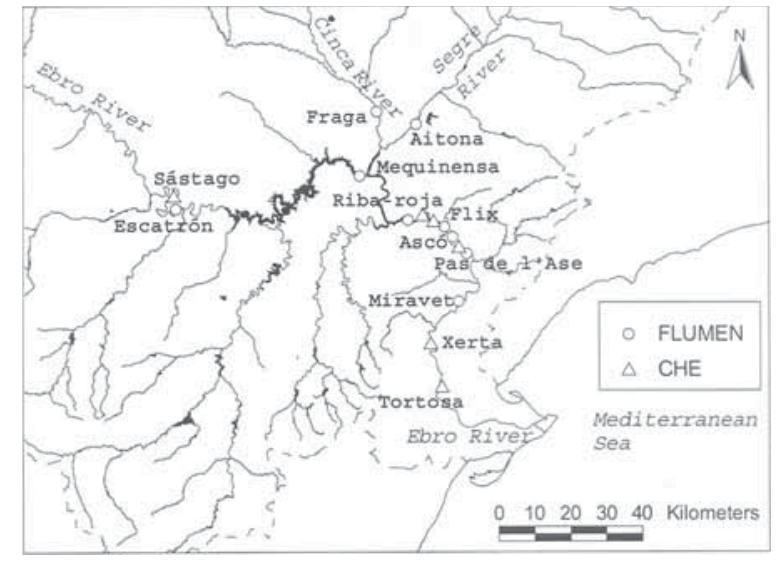

Figure 1. Location of the Flumen and CHE measuring stations mentioned in the text. Localización de las estaciones de la red de medida del grupo de investigación Flumen y de la CHE citadas en el texto.

\section{Climatic and hydrological trends in the area}

An increasing trend in air temperature of about $0.03-0.07^{\circ} \mathrm{C} /$ year over the last three decades of the twentieth century has been demonstrated in the Ebro basin and in the Iberian Peninsula in general (Seguí, 2003; Martín Vide, 2005; Moreno, 2005). In addition, the mean river discharge has been shown to have decreased by $5760 \mathrm{hm}^{3}$ in the period 1940-1997 (Gallart \& Llorens, 2001). The causes for this decrease include the construction of reservoirs all over the Ebro River basin (Ibáñez et al., 1999; Batalla et al., 2004); the increase in water consumption and in the irrigated land surface (Ibáñez et al., 1999; MIMAM, 2000); and a transient reduction of rainfall in the same period. A $4 \%$ decrease in precipitation in the Ebro River basin was observed in the period 1947-1999 (AyalaCarcedo, 2001). However, no significative trend can be detected in the long-term (García Vera et al., 2001; Moreno, 2005). Other authors indicate that afforestation could also be partly responsible for the decrease in discharge (Gallart \& Llorens, 2001). According to these authors, the losses in mean annual discharge observed in the period 1940-97 were distributed as follows: $1410 \mathrm{hm}^{3}$ due to consumption, $2140 \mathrm{hm}^{3}$ due to reduced precipitation and $2220 \mathrm{hm}^{3}$ to afforestation. 


\section{INSTRUMENTS AND DATA USED}

A system of water temperature measurement stations was installed in the lower part of the Ebro River and near the confluence of this river with the rivers Segre and Cinca (Fig. 1). Campbell Pt100 platinum resistance sensors (precision $0.1^{\circ} \mathrm{C}$ ) were used to measure the water temperature. Measurements were made every minute and the average was recorded every ten minutes by a Datalogger Campbell CR10X. Temperature sensors were duplicated or triplicated at every station to ensure the accuracy of the measured data and to prevent gaps in case of sensor malfunction. The sensors were installed inside PVC tubes to protect them from trunks, branches and other drifting objects. The tubes were perforated to allow the water to circulate freely. Part of the measured data used herein was previously published by one of the authors (Val, 2003).

The water temperature measurements taken at Escatrón were used in the reconstruction of the long-term annual mean water temperature series. They were also used in the process of validating the estimations of annual mean water temperature from the historical data. This process involved a resampling procedure (see below). Water temperature measurements (Fig. 2) taken at Aitona, Ascó, Flix, Fraga and Miravet (Fig. 1) were also used in the validation process.

\section{Historical data}

The historical data used in this study were provided by the Escatrón coal-fired power sta-

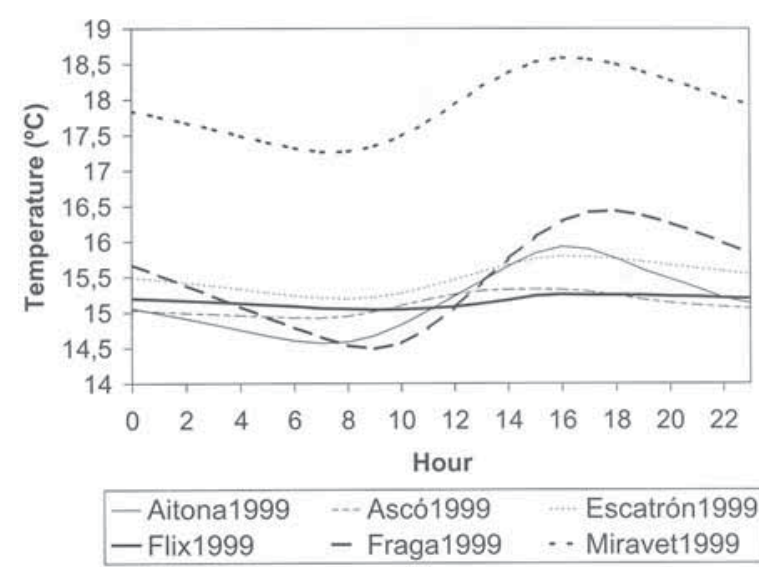

Figure 2. Average daily cycle in water temperature at Flumen stations in 1999. Ciclo diario medio de la temperatura del agua en estaciones Flumen en 1999.

tion and the Ebro Hydrographic Confederation (Table 1). The Escatrón power station provided two series of data. The first one, henceforth called EscatrónTE1, consisted of daily maximum and minimum water temperature measurements taken upstream from the thermal effluent of the power station in the years 1949-1977. This series has already been published by Arrúe \& Alberto (1986). The second series of data, called EscatrónTE2, consisted of daily water temperature measurements taken at $9 \mathrm{a} . \mathrm{m}$. in the period 1996-2000. These measurements were taken at the power station's water uptake point. Water temperature data at Escatrón for the period

Table 1. Historical water temperature data used, measurement period, type of measurement and estimator of the mean annual water temperature. Datos de temperatura históricos utilizados, periodo de medida, tipo de medida, y estimador de la temperatura media anual.

\begin{tabular}{|l|l|c|l|c|}
\hline Data series & Data source & Period of time & Type of measurement & $\begin{array}{c}\text { Annual mean water } \\
\text { temperature estimator }\end{array}$ \\
\hline EscatrónTE1 & $\begin{array}{l}\text { Power station of } \\
\text { Escatrón (Arrúe \& } \\
\text { Alberto, 1986) }\end{array}$ & $1949-1977$ & $\begin{array}{l}\text { Daily maximum and } \\
\text { minimum water } \\
\text { temperature }\end{array}$ & $T_{m_{1}}$ \\
\hline EscatrónTE2 & $\begin{array}{l}\text { Power station of } \\
\text { Escatrón }\end{array}$ & $1996-2000$ & $\begin{array}{l}\text { Daily water temperature } \\
\text { at 9 a.m. }\end{array}$ & $T_{m_{2}}$ \\
\hline SástagoCHE & CHE (Sástago) & $1975-2003$ & $\begin{array}{l}\text { Water temperature once } \\
\text { a month, at a varying } \\
\text { time of the day }\end{array}$ & $T_{m_{3}}$ \\
\hline
\end{tabular}




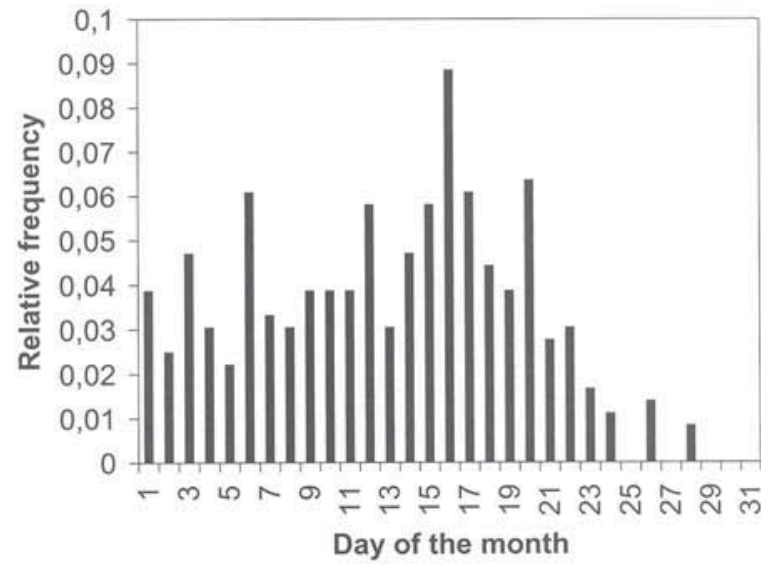

Figure 3. Frequency distribution of the day of the month on which CHE's water temperature measurements were made. Distribución de frecuencia del día del mes en que se tomaron las medidas de temperatura del agua de la CHE.

1978-1995 could not be found. To fill this gap, we used water temperature measurements taken at
Sástago by the Ebro Hydrographic Confederation (CHE). Sástago is located $17 \mathrm{~km}$ upstream from Escatrón (Fig. 1). Water temperature was measured at this site once a month, on a variable day of the month and at a varying time of day. This series of data will henceforth be called SástagoCHE.

The frequency distributions of the day of the month (Fig. 3) and the time of day (Fig. 4) at which the measurements were made at the CHE measuring stations of Ascó, Flix, Ribaroja, Sástago, Tortosa and Xerta were used in the process of validating the estimations of the mean annual water temperature made using the CHE data. In some cases (Sástago, Tortosa and Xerta), two periods can be seen in the CHE water temperature series in terms of the time of measurement (Fig. 4). Water temperatures were measured mostly in the morning in 19922004 at Tortosa (SDTortosa2), in 1993-2003 at Xerta (SDXerta2) and in 1974-1995 at
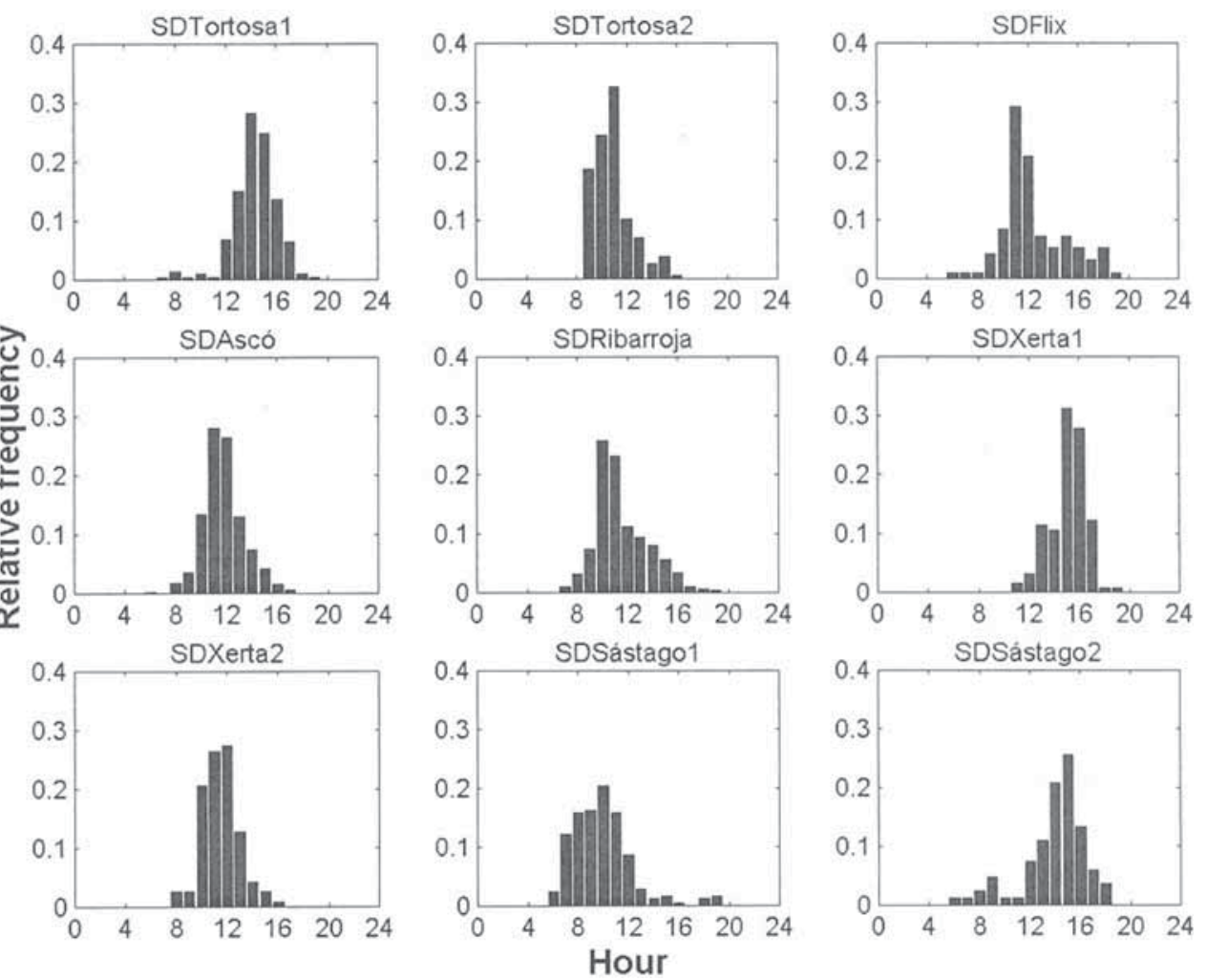

Figure 4. Frequency distribution of the time of day at which the CHE's water temperature measurements were made. Distribución de frecuencia de la hora del día en que se tomaron las medidas de temperatura del agua de la CHE. 
Sástago (SDSástago1), while temperatures were measured mostly in the afternoon the rest of the time (SDSástago2, SDTortosa1, SDXerta1).

\section{DATA ANALYSIS}

\section{Annual mean water temperature estimators}

The process of measuring water temperature at one or different times of year and making calculations with these measurements to estimate the annual mean water temperature can be considered an estimator of the mean annual water temperature. Different measuring methodologies and periodicities were used in the available data series. Therefore, this study includes three different estimators of the annual mean water temperature (Table 1).

\section{Estimator $T_{m_{1}}$}

This estimator is applied when daily measurements of maximum and minimum water temperature are available for a number of years, as in the EscatronTE1 data series. Firstly, the mean daily water temperature $\left(T_{i}\right)$ is estimated from the daily maximum and minimum water temperatures:

$$
T_{i}=\frac{T_{i, \max }+T_{i, \min }}{2}
$$

where $T_{i, \max }$ and $T_{i, \min }$ are the maximum and minimum water temperature on the $i$-th day of the year, respectively. Hence, the annual mean water temperature $\left(T_{m_{1}}\right)$ is estimated as the mean of all the $T_{i}$ values in a year:

$$
T_{m_{1}}=\frac{1}{365} \sum_{i=1}^{365} T_{i}=\frac{1}{365} \sum_{i=1}^{365} \frac{T_{i, \max }+T_{i, \min }}{2}
$$

\section{Estimator $T_{m_{2}}$}

This estimator can be used when the water temperature is measured every day at a fixed time of the day, as in the EscatronTE2 data. Firstly, an estimation of the annual water temperature is calculated as the mean of the daily measurements of water temperature taken at a given

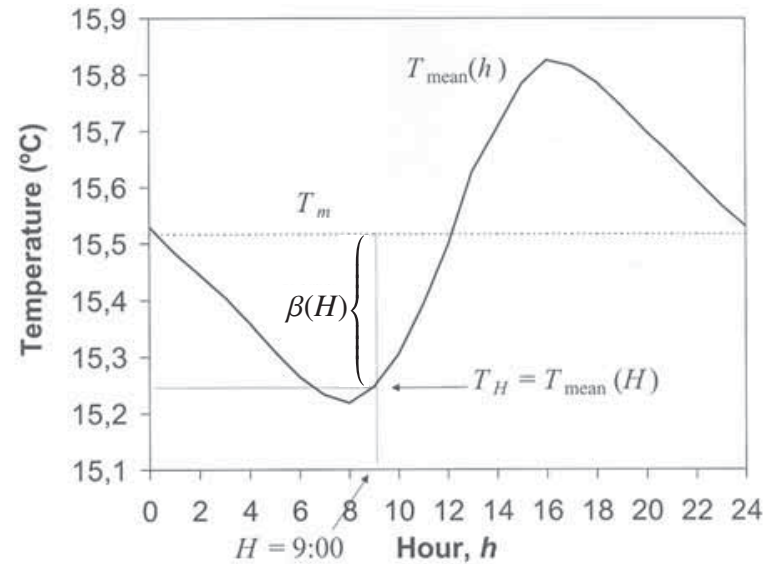

Figure 5. The average daily cycle in water temperature at Escatrón in 1999 and the bias of $T_{H}$ when $\mathrm{H}=9$ a.m. Ciclo diario de la temperatura del agua en Escatrón en 1999 y sesgo de $T_{H}$ cuando $H=9$ a.m.

time $H$ of the day:

$$
T_{H}=\frac{1}{365} \sum_{i=1}^{365} T_{i}(H)=T_{\text {mean day }}(H) .
$$

However, water temperature varies throughout the day according to an approximately sinusoidal cycle (Fig. 2). Therefore, $T_{H}$ is a poor estimator, as it is systematically biased. Unless daily point water temperature measurements are taken around the time when this almost sinusoidal curve crosses the mean, a bias $\beta$ is expected (Fig. 5). For a given time $H$ of the day, the bias may be calculated as:

$$
\beta(H)=T_{H}-T_{m}
$$

if we know the actual annual mean water temperature $T_{m}$. Therefore, a more accurate estimator of the annual mean water temperature can be obtained as:

$$
T_{m_{2}}=T_{H}-\beta(H) .
$$

\section{Estimator $T_{m_{3}}$}

The third estimator used herein is the mean of twelve water temperature measurements taken once a month on a variable day of the month and at varying times of day. This estimator is used for the CHE's measurements. 


\section{Statistical analysis of trends}

The Mann-Kendall nonparametric statistics have been widely used in water quality trend studies (Esterby, 1997). However, when there are gaps in the data series, the statistical methods used should take this fact into account. KendallTheil's robust line estimation method (Helsel and Hirsch, 1992) accounts for data gaps and was used to estimate the water temperature trend. According to this method, the slope of the linear trend is calculated as the median of all the possible pairwise slopes between the data points.

\section{RESULTS}

\section{Validation of the estimations}

Different methods were used to validate the estimations of the annual mean water temperature, depending on the type of data and the estimator used. Most of the methods were based on imitating the respective measurement process by resampling the Flumen 10-minutes data series. The details of the process used for each of the estimators are given below.

Table 2. Annual mean water temperature, $T_{m}$, estimations of the annual mean water temperature made using $T_{m_{1}}$ and the error of the estimation at selected Flumen stations. Temperatura media anual del agua, $T_{m}$, estimaciones de la temperatura media anual hechas con $T_{m_{1}}$ y error de la estimación en estaciones seleccionadas del grupo Flumen.

\begin{tabular}{|l|c|c|c|c|}
\hline Station & Year & $T_{m}\left({ }^{\circ} \mathbf{C}\right)$ & $T_{m_{1}}\left({ }^{\circ} \mathbf{C}\right)$ & Error $\left({ }^{\circ} \mathbf{C}\right)$ \\
\hline Aitona & 1999 & 15.161 & 15.233 & 0.072 \\
\hline Ascó & 1999 & 15.110 & 15.138 & 0.028 \\
& 2000 & 15.184 & 15.225 & 0.041 \\
& 2001 & 15.338 & 15.378 & 0.040 \\
& 2002 & 15.094 & 15.140 & 0.046 \\
& 2003 & 15.564 & 15.602 & 0.038 \\
\hline Escatrón & 1998 & 15.333 & 15.356 & 0.023 \\
& 1999 & 15.515 & 15.542 & 0.027 \\
\hline Flix & 1998 & 15.218 & 15.248 & 0.030 \\
& 1999 & 15.150 & 15.188 & 0.038 \\
\hline Fraga & 1999 & 15.479 & 15.496 & 0.017 \\
\hline Miravet & 1999 & 17.906 & 17.968 & 0.062 \\
& 2000 & 17.929 & 17.988 & 0.059 \\
& 2001 & 17.687 & 17.692 & 0.005 \\
& 2002 & 18.160 & 18.165 & 0.005 \\
& 2003 & 17.796 & 17.791 & -0.005 \\
\hline
\end{tabular}

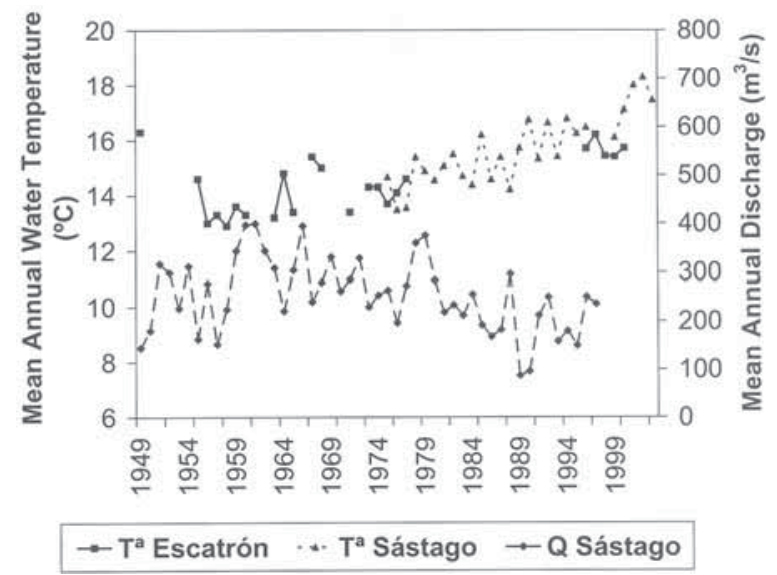

Figure 6. Mean annual water temperature at Escatrón and Sástago, and the mean annual discharge at Sástago (longdashed line, data provided by the CHE). Temperatura media anual del agua en Escatrón y Sástago, y caudal medio anual en Sástago (datos proporcionados por la CHE).

\section{$T_{m_{1}}$ validation}

Ten-minute Flumen water temperature measurements were used to assess the accuracy of $T_{m_{1}}$. Annual mean water temperature was estimated by applying $T_{m_{1}}$ to Flumen's data for different measurement stations and years. The result was compared with the actual annual mean water temperature $T_{m}$. The results in Table 2 show that estimations calculated using the estimator $T_{m_{1}}$ are very accurate. All the estimated biases are lower than the sensor accuracy of $0.1^{\circ} \mathrm{C}$. Therefore, if no other sources of error are present, we can consider $T_{m_{1}}$ to be a good estimator of annual mean water temperature. Thus, the estimator $T_{m_{1}}$ was used to estimate mean annual water temperature from the EscatrónTE1 data series, which consists of maximum and minimum daily water temperature measurements taken in the period 1949-1977 (Fig. 6).

\section{$T_{m_{2}}$ validation}

The accuracy of the estimations obtained using $T_{m_{2}}$ was assessed in two ways. Firstly, $T_{H}(9: 00)$ was calculated using EscatrónTE2 data for the years 1998-1999. This value was then compared to $T_{m}$ for the same years to obtain the bias. Next, $T_{H}(9: 00)$ was calculated again 
Table 3. Comparison of two methods for calculating the bias in the estimation of the annual mean water temperature at Escatrón using $T_{m_{2}}$ (see text for details). Comparación de dos métodos de estimación del sesgo de la estimación de la temperatura media anual producida al usar $T_{m_{2}}$ (ver detalles en el texto).

\begin{tabular}{|l|c|c|c|c|}
\hline Data source & Year & $T_{m}$ & $T_{m_{2}}$ & Bias \\
\hline EscatronUPC & 1998 & 15.33 & 15.02 & -0.31 \\
& 1999 & 15.52 & 15.22 & -0.30 \\
& Mean 1998-99 & 15.42 & 15.12 & -0.30 \\
\hline EscatronTE2 & 1998 & 15.33 & 15.17 & -0.16 \\
& 1999 & 15.52 & 15.15 & -0.37 \\
& Mean 1998-99 & 15.42 & 15.16 & -0.26 \\
\hline
\end{tabular}

using EscatrónUPC data. The mean bias resulted in an underestimation of approximately $0.3^{\circ} \mathrm{C}$ (Table 3). Nevertheless, a discrepancy appeared between the bias calculated using EscatrónUPC data and that calculated with EscatronTE2 data. The bias calculated from EscatrónUPC data changed very little from 1998 to 1999. However, with EscatrónTE2 data the bias was -0.16 in 1998 and -0.37 in 1999. This discrepancy disappeared when the mean of the two years was calculated. We had to decide which of the two estimations of the mean bias to use. Preference was given to the bias calculated from EscatrónTE2 data, as it would be applied to this same data series. Therefore, the value of $\beta(9: 00)=-0.26$ was substituted in (5) to obtain a more accurate value of the mean annual water temperature. The corrected annual mean water temperatures at Escatrón for 1996-2000 can be seen in figures 6 and 7 .

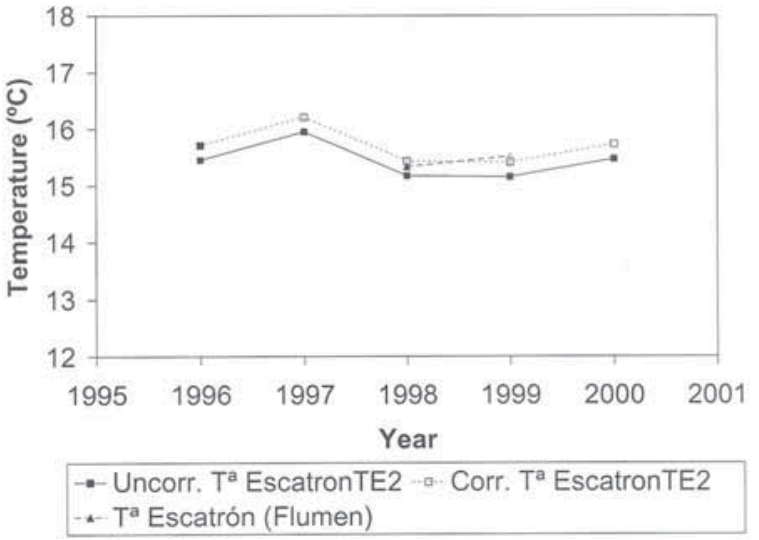

Figure 7. Corrected (white squares) and uncorrected (black squares) estimation of the annual mean water temperature at Escatrón, calculated using EscatronTE2 data and the annual mean water temperature for 1998-1999 (triangles). Estimación corregida (cuadrados blancos) y sin corregir (cuadrados negros) de la temperatura media anual en Escatrón usando los datos de EscatronTE2 y temperatura media anual de los años 1998-1999.

\section{$T_{m_{3}}$ validation}

The estimations calculated with $T_{m_{3}}$ were validated by simulating the CHE measuring methodology on 10-minute Flumen water temperature measurements taken in 1999 from different measuring stations: Aitona, Ascó, Escatrón, Flix, Fraga, and Miravet (Fig. 1). The mean expected bias and standard deviation of the estimations of the mean annual water temperature were calculated for different time of measurement patterns: SDAscó, SDFlix, SDRiba-roja, SDSástago1, SDSástago2, SDTortosa1, SDTor tosa2, SDXerta1, SDXerta2 (Tables 4 and 5). The

Table 4. Mean bias of $T_{m_{3}}$ for different Flumen stations and different frequency distributions for the time of measurement. Sesgo medio de $T_{m_{3}}$ para diferentes estaciones Flumen y distribuciones de frecuencia de la hora de medida.

\begin{tabular}{|c|c|c|c|c|c|c|c|c|c|c|c|}
\hline & SDTortosa1 & SDTortosa2 & SDFlix & SDAscó & SDRiba-roja & SDXerta1 & SDXerta2 & SDSástago1 & SDSástago2 & $\begin{array}{c}\text { Mean bias } \\
\left({ }^{\circ} \mathrm{C}\right)\end{array}$ & $\begin{array}{c}\text { Temp. range } \\
\left({ }^{\circ} \mathrm{C}\right)\end{array}$ \\
\hline TAitona1999 & 0.41 & -0.22 & 0.05 & -0.01 & -0.09 & 0.53 & -0.11 & -0.37 & 0.32 & 0.06 & 1.65 \\
\hline TAscó1999 & 0.20 & 0.04 & 0.11 & 0.11 & 0.09 & 0.17 & 0.07 & -0.06 & 0.15 & 0.10 & 0.72 \\
\hline TEscatrón1999 & 0.05 & -0.21 & -0.10 & -0.17 & -0.18 & 0.11 & -0.16 & -0.26 & 0.00 & -0.10 & 0.83 \\
\hline TFlix1999 & 0.01 & -0.09 & -0.05 & -0.05 & -0.09 & 0.04 & 0.36 & -0.13 & -0.02 & 0.00 & 0.64 \\
\hline TFraga1999 & 0.27 & -0.74 & -0.35 & -0.48 & -0.58 & 0.44 & -0.60 & -0.77 & 0.18 & -0.29 & 2.17 \\
\hline TMiravet1999 & 0.47 & -0.19 & 0.05 & 0.01 & -0.07 & 0.56 & -0.10 & -0.39 & 0.41 & 0.08 & 1.70 \\
\hline $\begin{array}{c}\text { Mean bias } \\
\left({ }^{\circ} \mathrm{C}\right)\end{array}$ & 0.23 & -0.23 & -0.05 & -0.10 & -0.15 & 0.31 & -0.09 & -0.33 & 0.17 & & \\
\hline $\begin{array}{l}\text { Median hour } \\
\text { of measurement }\end{array}$ & $14: 00$ & 11:00 & $12: 00$ & 12:00 & 11:00 & $15: 00$ & $12: 00$ & 10:00 & $14: 30$ & & \\
\hline
\end{tabular}


Table 5. Standard deviation of $T_{m_{3}}$ for different Flumen stations and different frequency distributions for the time of measurement. Desviación estándar de $T_{m_{3}}$ para diferentes estaciones Flumen y distribuciones de frecuencia de la hora de medida.

\begin{tabular}{|c|c|c|c|c|c|c|c|c|c|c|c|}
\hline & SDTortosa1 & SDTortosa2 & SDFlix & SDAscó & SDRiba-roja & SDXerta1 & SDXerta2 & SDSástago 1 & SDSástago2 & $\begin{array}{c}\text { mean Std. } \\
\text { Dev. }\end{array}$ & $\begin{array}{c}\text { Temp. range } \\
\left({ }^{\circ} \mathrm{C}\right)\end{array}$ \\
\hline TAitona1999 & 0.37 & 0.37 & 0.39 & 0.45 & 0.40 & 0.37 & 0.37 & 0.36 & 0.39 & 0.39 & 1.65 \\
\hline TAscó1999 & 0.25 & 0.26 & 0.25 & 0.27 & 0.24 & 0.29 & 0.27 & 0.26 & 0.25 & 0.26 & 0.72 \\
\hline TEscatrón1999 & 0.38 & 0.40 & 0.41 & 0.40 & 0.42 & 0.43 & 0.40 & 0.41 & 0.38 & 0.40 & 0.83 \\
\hline TFlix 1999 & 0.25 & 0.26 & 0.25 & 0.25 & 0.26 & 0.24 & 0.40 & 0.24 & 0.24 & 0.27 & 0.64 \\
\hline TFraga1999 & 0.46 & 0.42 & 0.46 & 0.46 & 0.46 & 0.46 & 0.44 & 0.47 & 0.47 & 0.46 & 2.17 \\
\hline TMiravet1999 & 0.31 & 0.27 & 0.30 & 0.31 & 0.31 & 0.29 & 0.30 & 0.29 & 0.33 & 0.30 & 1.70 \\
\hline $\begin{array}{l}\text { mean Std. } \\
\text { Dev. }\end{array}$ & 0.34 & 0.33 & 0.34 & 0.35 & 0.35 & 0.34 & 0.36 & 0.34 & 0.34 & & \\
\hline $\begin{array}{l}\text { Median hour } \\
\text { of measurement }\end{array}$ & $14: 00$ & 11:00 & 12:00 & $12: 00$ & 11:00 & 15:00 & $12: 00$ & 10:00 & $14: 30$ & & \\
\hline
\end{tabular}

distribution of the day of measurement was considered to be the same for all of the measuring stations (Fig. 3). Thus, by combining different locations and times of measurement, a range of environmental conditions was stimulated that was wide enough to reveal the general and extreme behaviour of the estimator $T_{m_{3}}$.

The process of simulating the CHE measuring methodology is detailed here for clarity. A Flumen measuring station was chosen and its water temperature data for the year 1999 was extracted (e.g. TEscatrón1999, the 10-minute water temperature data measured at Escatrón during 1999). Then 12 values were randomly generated

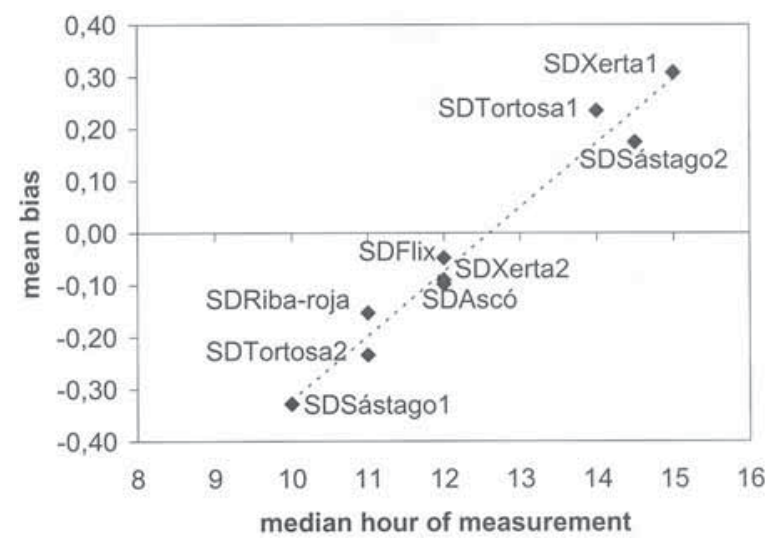

Figure 8. Mean bias of $T_{m_{3}}$ for different time of measurement frequency distributions according to the median hour of measurement. Sesgo medio de $T_{m_{3}}$ para diferentes distribuciones de frecuencia de la hora de medida en función de la mediana de la hora de medida. for the hour and day of measurement, according to one of the frequency distributions for the time of measurement (Fig. 4) and the frequency distribution for the day of measurement (Fig. 3) (e.g. SDSástago1, the frequency distribution for the time of measurement at Sástago from 1974 until 1995). By means of repeated sampling $(n=300)$ for that station and time of measurement pattern, it was possible to calculate the statistical properties of the estimator $T_{m_{3}}$ (Tables 4 and 5). The mean expected bias was also calculated as:

$$
\bar{\beta}=\bar{T}_{m_{3}}-T_{m}
$$

According to our calculations, the estimator $T_{m_{3}}$ follows a normal distribution (KolmogorovSmirnov test, $p>0.05$ ). The mean expected bias had values of between -0.77 and $0.56^{\circ} \mathrm{C}$ (Table 4 ) and standard deviation of between 0.235 and $0.473^{\circ} \mathrm{C}$ (Table 5). Bias varied according to the time of measurement and the daily water temperature ranges (Fig. 8, Table 4). Positive biases appeared when measurements were taken mostly in the afternoon. Negative biases were found when the measurements were made in the morning. The bias and standard deviation of the estimations tended to be higher when there were wider daily water temperature ranges (Tables 4 and 5). Standard deviation did not seem to be greatly affected by the median time of the measurements (Table 5).

These results imply that a priori, the estimator $T_{m_{3}}$ cannot be considered to be unbiased or 
Table 6. Estimated annual mean water temperature at Escatrón and Sástago in the years when the data series at both sites overlap. Temperatura media anual estimada en Escatrón y Sástago en los años en que las series de datos de ambas localidades se solapan.

\begin{tabular}{|c|c|c|c|}
\hline Year & $\begin{array}{c}\text { Mean annual water } \\
\text { temp. at Escatrón }\left({ }^{\circ} \mathbf{C}\right)\end{array}$ & $\begin{array}{c}\text { Mean annual water } \\
\text { temp. at Sástago } \\
\text { estimated with } T_{m_{3}}\left({ }^{\circ} \mathbf{C}\right)\end{array}$ & Difference $\left({ }^{\circ} \mathbf{C}\right)$ \\
\hline 1975 & 13.65 & 14.68 & -0.62 \\
\hline 1976 & 14.11 & 13.49 & -1.07 \\
\hline 1977 & 14.63 & 13.56 & --- \\
\hline--- & --- & --- & - \\
\hline 1996 & 15.71 & 16.49 & - \\
\hline 1997 & 16.21 & - & 0.78 \\
\hline 1998 & 15.43 & - & 16.12 \\
\hline 1999 & 15.41 & 17.13 & 1.40 \\
\hline 2000 & 15.73 & & \\
\hline
\end{tabular}

to have little standard deviation. In addition, bias cannot be estimated in the case of the SástagoCHE data series, given that hourly or 10-minute measurements are not available for Sástago. Furthermore, the SástagoCHE data series should be divided into two: the period 1974-1995, when most of the measurements were taken in the morning; and 1996-2004, when most of the measurements where taken in the afternoon (Fig. 4). According to our results, the mean expected bias should be different for the two periods of time. This fact is supported by a comparison of the overlap between the Escatrón and Sástago data series (Fig. 6, Table 6).

\section{Water temperature trend}

The validation of the estimators showed that the estimations of the annual mean water temperature at Escatrón using the estimator $T_{m_{1}}$ and EscatronTE1 data for the period 19491977 were very accurate. The estimations made with $T_{m_{2}}$ and EscatronTE2 data for 1996-2000 were sufficiently accurate after calculating the bias. In contrast, estimations made using $T_{m_{3}}$ had a rather high variability and a bias that was difficult to determine without knowing the daily water temperature cycle at the point of interest. For this reason, SástagoCHE data were not used in the analysis of the long-term water temperature trend. Only the data from Escatrón were used. The mean annual water temperature at Escatrón is shown in figure 6 along with the annual mean discharge. The annual mean water temperature estimations at Sástago are also shown for descriptive purposes only.

The annual mean water temperature at Escatrón increased from 1955 to 2000. The rate of increase was estimated with the Kendall-Theil robust line estimator. Water temperature increased $0.051^{\circ} \mathrm{C} /$ year $(95 \%$ confidence interval: 0.027 0.067 ) in the period $1955-2000$, or $2.3^{\circ} \mathrm{C}$ in this 46-year-long period. This increase in water temperature is negatively correlated with a decrease in discharge (Fig. 6) and positively correlated with an increase in air temperature.

\section{DISCUSSION}

\section{Estimation of the annual mean water temperature}

The results show that the water temperature measuring methodology affects the accuracy of the annual mean water temperatures estimated from the data. The bias in absolute values can be as great as $0.8^{\circ} \mathrm{C}$. Standard deviations can 
be almost as high as $0.5^{\circ} \mathrm{C}$. Variations in values depend on the measurement methodology, the time of measurement and the mean daily water temperature range at the point of measurement.

Of the three annual mean water temperature estimators, $T_{m_{1}}$ was shown to be the most accurate. It had a bias of less than $0.1^{\circ} \mathrm{C}$. In fact, early studies on water temperature in rivers used maximum and minimum water temperature measurements (e.g. Edington, 1965) and stated that they provided 'a reasonably satisfactory average temperature' (Macan, 1959).

As expected, the estimator $T_{m_{2}}$ was consistently biased. The bias depended on the daily water temperature range and the time of measurement (Fig. 5). Given that 10-minute water temperature measurements were available for two of the years for which this estimator had to be applied, it could be calculated using (4) (Table 3). A slight difference appeared when the annual biases for 1998 and 1999 were estimated by calculating $T_{H}(9: 00)$ in (4) using either EscatrónTE2 or EscatrónUPC data. However, when the mean of the two years was used the differences disappeared. The differences may be due to the presence of gaps in the data series (less than $5 \%$ of the measurements) or other reasons (e.g. different points of measurement) that could cause an additional bias. The effect of gaps on the estimation of the mean annual water temperature has not been considered herein, as the mean annual water temperature was not calculated for the years when the missing data accounted for more than $5 \%$ of the annual data.

The results showed $T_{m_{3}}$ to be the poorest of the three estimators. In addition to being biased, it has a significant dispersion. As in the case of the former estimator, bias depended on the median time of measurement and on the daily water temperature range. The standard deviation of the bias also depended on the daily water temperature range.

The implications of these results for the estimation of annual mean water temperatures from historical data are significant. Data series that consist of daily maximum and minimum water temperatures can be used confidently, whereas data series that have consistent measurements at or around a particular time of the day cannot be used unless we can estimate the bias or ensure that there is no significant bias.

\section{Water temperature increase}

Water temperature behaviour in the middle and lower courses of rivers with relatively high discharges is a complex phenomenon, as it depends on processes that take place on different scales. The thermal inertia inherent in high discharges makes the water temperature at the lower or medium course of a river dependent on events that take place many kilometres upstream as well as on local processes. At Escatrón, the effects of the origin of the water (rainfall, snowmelt, etc.) on the water temperature can still be felt (Arrúe \& Alberto, 1986).

Alberto \& Arrúe (1986) detected an increase in the annual mean water temperature of the Ebro River at Escatrón. This study extended the study period to 1955-2000. The results showed that the water temperature increased $2.3^{\circ} \mathrm{C}$ between 1955 and 2000. This increase seems to be related to an increase in air temperature and a decrease in discharge (Fig. 6). Empirical correlations show that an increase in the air temperature generally implies an increase in the water temperature (Webb \& Nobilis, 1997; Mohseni \& Stefan, 1999). In addition, a decrease in discharge leads to lower thermal inertia. This effect is greatest in the summer when the river discharge is lowest (Meier et al., 2003). The final effect on the annual mean water temperature would be an increase. Alberto \& Arrúe (1986) suggested other possible human causes for the increase in water temperature, including thermal inflows, etc. However, a study at the basin scale is required to determine the precise effect of these or other factors on the water temperature.

\section{CONCLUSIONS}

The quality of the measurements must be assessed when working with historical water temperature data. Because of the daily variability in water temperature, the estimations of the annual 
mean water temperature based on measurements taken at or around a given time of day are biased. In this case, the bias depends on the time of the measurement and on the mean daily water temperature range. In some cases, the bias may be estimated and the estimations of the annual mean water temperature corrected accordingly. Estimations of the annual mean water temperature that are based on daily measurements of maximum and minimum water temperatures can be considered unbiased.

At Escatrón, the annual mean water temperature series could be reconstructed from historical data for 1949-2000, although a gap between 1978 and 1995 could not be filled in. This series shows a $2.3^{\circ} \mathrm{C}$ increase in annual mean water temperature in the period 1955-2000.

\section{AKNOWLEDGEMENTS}

We are grateful to José Luis Arrúe from the Estación Experimental Aula Dei at Zaragoza for his help and kindness and to the Escatrón power plant for allowing us to use their water temperature data. We also thank R. Marcé for his comments, which helped to improve the previous version of the manuscript. This study was funded by the Programa de Recursos Hídricos del Plan Nacional de Investigación $y$ Desarrollo and the Social European Fund, project numbers CGL2004-05503-C02-01/HID and CGL2004-05503-C02-02/HID.

\section{REFERENCES}

ALBERTO, F. \& J. L. ARRÚE. 1986. Anomalías térmicas en algunos tramos de la red hidrográfica del Ebro. Anales de la Estación Experimental Aula Dei, 18: 91-113.

ÁlVAREZ COBELAS, M., J. CATALÁN \& D. GARCÍA DE JALÓN. 2005. Impactos sobre los ecosistemas acuáticos continentales. In: Evaluación preliminar de los impactos en España por efecto del cambio climático. J. M. Moreno (Coord.): 113-146. Ministerio de Medio Ambiente, Madrid, España.
ARRÚE, J. L. \& F. ALBERTO. 1986. El régimen térmico de las aguas superficiales de la Cuenca del Ebro. Anales de la Estación Experimental Aula Dei, 18: 31-50.

AYALA-CARCEDO, F. J. 2001. Impactos del cambio climático sobre los recursos hídricos en España y viabilidad del Plan Hidrológico Nacional 2000. In: El Plan Hidrológico Nacional a debate. P. Arrojo (coord.): 51-66. Bakeaz, Bilbao, España.

BATALLA, R. J., C. M. GÓMEZ \& G. M. KONDOLF. 2004. Reservoir-induced hydrological changes in the Ebro River baisin (NE Spain). $J$. Hydrol., 290: 117-136.

BEAUCHAMP, R. S. A.\& P. ULLYOTT. 1932. Competitive relationships between certain species of fresh-water triclads. The Journal of Ecology, 20 (1): 200-208.

EDINGTON, J. M. 1965. Some observations on stream temperature. Oikos 15: 265-273.

ESTERBY, S. R. 1997. Review of methods for the detection and estimation of trends with emphasis on water quality applications. In: Water quality trends and geochemical mass balance, N. E. Peters, O. P. Bricker \& M. M. Kennedy (eds.): 325. John Wiley \& Sons, Chichester.

GALLART, F. \& P. LLORENS. 2001. Water resources and environmental change in Spain. A key issue for sustainable integrated catchment management. Cuadernos de Investigación Geográfica, 27: 7-16.

GARCÍA VERA, M. A. 2001. Las precipitaciones en la cuenca del Ebro: caracterización de la evolución espacio temporal y análisis de tendencias. Confederación Hidrográfica del Ebro, Oficina de Planificación Hidrológica, Zaragoza. 114 pp.

HARVELL, C. D., C. E. MITCHELL, J. R. WARD, S. ALTIZER, A. P. DOBSON, R. S. OSTFELD $\&$ M. D. SAMUEL. 2002. Climate warming and disease risks for terrestrial and marine biota. Science, 296: 2158-2162.

HELSEL, D. R. \& R. M. HIRSCH. 1992. Statistical methods in water resources. Elsevier, Amsterdam. $522 \mathrm{pp}$.

HELLAWELL, J. M. 1986. Biological indicators of freshwater pollution and environment management. Elsevier, London. 546 pp.

HOGG, I. D. \& D. D. WILLIAMS. 1996. Response of stream invertebrates to a global-warming thermal regime: an ecosystem level manipulation. Ecology, 77 (2): 395-407. 
IBÁÑEZ, C., N. PRAT, A. CANICIO \& A. CURCÓ. 1999. El delta del Ebro, un sistema amenazado. Bakeaz, Bilbao. 109 pp.

LIVINGSTONE, D. M. 2003. Impact of secular climate change on the thermal structure of a large temperate Central European lake. Climatic Change, 57: 205-225.

McADAM, S. 2000. Summary of historic and contemporary water temperatures for the Columbia River and the potential effects of impoundment. Province of British Columbia, Fisheries Technical Circular $\mathrm{N}^{\mathrm{o}} 103.25 \mathrm{pp}$.

McCARTY, J. P. 2001. Ecological consequences of recent climate change. Biological Conservation, 15 (2): 320-331.

MACAN, T. T. 1959. The temperature of a small stony stream. Hydrobiologia, 12: 89-106.

MARTÍN VIDE, J. 2005. Factors geogràfics, regionalització climàtica, i tendències de les sèries climàtiques a Catalunya. In: Informe sobre el canvi climàtic a Catalunya. J. E. Llebot, A. Queralt i J. Rodó (eds.): 81-111. Departament de la Presidència. Consell Assessor per al Desenvolupament Sostenible de Catalunya (CADS). Barcelona.

MEIER, W., C. BONJOUR, A. WÜEST \& P. REICHERT. 2003. Modeling the Effect of Water Diversion on the Temperature of Mountain Streams. J. Environ. Engineering, 129: 755-764.

MIMAM. 2000. Plan Hidrológico Nacional. Análisis de los sistemas hidráulicos. Ministerio de Medio Ambiente. Madrid. 390 pp.

MOHSENI, O. \& H. G. STEFAN. 1999. Stream temperature/air temperature relationship: a physical interpretation. J. Hidrol., 218: 128-141.

MORENO, J. M. (coord.) 2005. Evaluación preliminar de los impactos en España por efecto del cambio climático. Ministerio de Medio Ambiente, Madrid, España. 822 pp.

NEGUS, C. L. 1966. A quantitative study of growth and production of Unionid mussels in the river Thames at Reading. J. Anim. Ecol., 35 (3):513-532.

PREECE, R. M. \& H. A. JONES. 2002. The effect of Keepit Dam on the temperature regime of the Namoi River, Australia. River Research and Applications, 18: 397-414.

PRITCHARD, G., L. D. HARDER, \& R. A. MUTCH. 1996. Development of aquatic insect eggs in relation to temperature and strategies for dealing with different thermal environments. Biological Journal of the Linnean Society, 58: 221-244.

REEVES, G. H., F. H. EVEREST \& J. D. HALL. 1987. Interactions between the Redside Shiner (Richardsonius balteatus) and the Steelhead Trout (Salmo gardnieri) in Western Oregon: the influence of water temperature. Can. J. Fish. Aquat. Sci., 44: 1603-1613.

REMPEL, R. S. \& J. C. H. CARTER. 1987. Temperature influences on adult size, development, and reproductive potential of aquatic diptera. Can. J. Fish. Aquat. Sci., 44: 1743-1752.

SCHINDLER, D. W. 1997. Widespread effects of climatic warming on freshwater ecosystems in North America. Hydrological Processes, 11: 10431067.

SEGUÍ, J. 2003. Análisis de la serie de temperatura del Observatorio del Ebro 1894-2002. Observatori de l'Ebre: Roquetes. 83 pp.

TANIGUCHI, Y., F. J. RAHEL, D. C. NOVINGER \& K. G. GEROW. 1998. Temperature mediation of competitive interactions among three fish species that replace each other along longitudinal stream gradients. Can. J. Fish. Aquat. Sci., 55: 1894-1901.

VAL, R. 2003. Incidencia de los embalses en el comportamiento térmico del río Ebro. Caso del sistema de embalses Mequinenza-Ribarroja-Flix en el río Ebro. $\mathrm{PhD}$ Thesis, Technical University of Catalonia. $196 \mathrm{pp}$.

WALTHER, G. R., E. POST, P. CONVEY, A. MENZEL, C. PARMESAN, T. J. C. BEEBEE, J. M. FROMENTIN, O. HOEGH-GULDBERG \& F. BAIRLEIN. 2002. Ecological responses to recent climate change. Nature, 416: 389-395.

WEBB, B. W. \& F. NOBILIS. 1994. Water temperature behaviour in the River Danube during the twentieth century. Hydrobiologia, 291: 105-113.

WEBB, B. W. \& F. NOBILIS. 1997. Long-term perspective on the nature of the air-water temperature relationship: a case study. Hydrological Processes, 137: 137-147.

WIESER, W., H. FORSTNER, F. SCHIEMER, \& W. MARK. 1988. Growth rates and growth efficiencies in larvae and juveniles of Rutilus rutilus and other Cyprinid species: effects of temperature and food in the laboratory and in the field. Can. J. Fish. Aquat. Sci., 45: 943-950.

WINFIELD, I. J. \& J. S. NELSON. 1991. Cyprinid fishes. Systematics, biology and exploitation. Chapman \& Hall, London. 667 pp. 